\title{
Implications of Glycosaminoglycans on Viral Zoonotic Diseases
}

\author{
Sarah Bauer ${ }^{1} \mathbb{D}$, Fuming Zhang ${ }^{1,2, *(\mathbb{D})}$ and Robert J. Linhardt $1,2,3, * \mathbb{D}$ \\ 1 Department of Chemistry and Chemical Biology, Center for Biotechnology and Interdisciplinary Studies, \\ Rensselaer Polytechnic Institute, Troy, NY 12180, USA; Bauers2@rpi.edu \\ 2 Department of Chemical and Biological Engineering, Center for Biotechnology and Interdisciplinary Studies, \\ Rensselaer Polytechnic Institute, Troy, NY 12180, USA \\ 3 Departments of Biological Science, Biomedical Engineering, Center for Biotechnology and Interdisciplinary \\ Studies, Rensselaer Polytechnic Institute, Troy, NY 12180, USA \\ * Correspondence: zhangf2@rpi.edu (F.Z.); linhar@rpi.edu (R.J.L.)
}

Citation: Bauer, S.; Zhang, F.; Linhardt, R.J. Implications of Glycosaminoglycans on Viral Zoonotic Diseases. Diseases 2021, 9, 85 . https://doi.org/10.3390/

diseases 9040085

Academic Editor: Charles Bodet

Received: 13 October 2021

Accepted: 15 November 2021

Published: 17 November 2021

Publisher's Note: MDPI stays neutral with regard to jurisdictional claims in published maps and institutional affiliations.

Copyright: (C) 2021 by the authors. Licensee MDPI, Basel, Switzerland. This article is an open access article distributed under the terms and conditions of the Creative Commons Attribution (CC BY) license (https:/ / creativecommons.org/licenses/by/ $4.0 /)$.

\begin{abstract}
Zoonotic diseases are infectious diseases that pass from animals to humans. These include diseases caused by viruses, bacteria, fungi, and parasites and can be transmitted through close contact or through an intermediate insect vector. Many of the world's most problematic zoonotic diseases are viral diseases originating from animal spillovers. The Spanish influenza pandemic, Ebola outbreaks in Africa, and the current SARS-CoV-2 pandemic are thought to have started with humans interacting closely with infected animals. As the human population grows and encroaches on more and more natural habitats, these incidents will only increase in frequency. Because of this trend, new treatments and prevention strategies are being explored. Glycosaminoglycans (GAGs) are complex linear polysaccharides that are ubiquitously present on the surfaces of most human and animal cells. In many infectious diseases, the interactions between GAGs and zoonotic pathogens correspond to the first contact that results in the infection of host cells. In recent years, researchers have made progress in understanding the extraordinary roles of GAGs in the pathogenesis of zoonotic diseases, suggesting potential therapeutic avenues for using GAGs in the treatment of these diseases. This review examines the role of GAGs in the progression, prevention, and treatment of different zoonotic diseases caused by viruses.
\end{abstract}

Keywords: zoonotic diseases; infection; glycosaminoglycans; virus; COVID-19; SARS-CoV-2

\section{Introduction}

Zoonotic diseases are infectious diseases originating in animals, either symptomatic or asymptomatic, that can be passed to humans through exposure incidents referred to as spillovers [1]. Viruses transmitted through animals cause many of the world's most problematic and contagious diseases [2]. HIV passes from apes to humans, Hendra passes through horses to humans, and Ebola passes from bats to humans. There have been eight major outbreaks globally that were caused by zoonotic spillovers since 1990 [3] (Table 1). As humans encroach further on natural habitats, these spillovers become more likely [4]. With the recent COVID-19 pandemic, the need for scientific research and understanding of zoonotic illnesses has become imperative. An overview of global outbreaks of zoonotic diseases during the last half-century is shown in Table 1.

Table 1. Zoonotic diseases outbreaks by year, location, and strains [5-10].

\begin{tabular}{ccl}
\hline Year & Location & Virus/Strain \\
\hline 1976 & Zaire (Now DRC) & Ebola Zaire \\
\hline 1976 & Sudan (Now South Sudan) & Ebola Sudan \\
\hline 1976 & U.K. & Ebola Sudan \\
\hline 1989 & Philippines & Ebola Reston \\
\hline
\end{tabular}


Table 1. Cont.

\begin{tabular}{|c|c|c|}
\hline Year & Location & Virus/Strain \\
\hline 1990 & U.S. & Ebola Reston \\
\hline 1994 & Gabon & Ebola Zaire \\
\hline 1994 & Mackay, Australia & Hendra \\
\hline 1994 & Brisbane, Australia & Hendra \\
\hline 1995 & DRC & Ebola Zaire \\
\hline 1996 & South Africa & Ebola Zaire \\
\hline 1996 & Russia & Ebola Zaire \\
\hline 1998 & Malaysia & Nipah \\
\hline 1999 & Cairns, Australia & Hendra \\
\hline 2000 & Uganda & Ebola Zaire \\
\hline 2001 & Gabon & Ebola Zaire \\
\hline 2001 & Bangladesh & Nipah \\
\hline 2002 & Republic of Congo & Ebola Zaire \\
\hline 2002 & Bangladesh & Nipah \\
\hline 2003 & Bangladesh & Nipah \\
\hline 2003 & Guangdong, China & SARS \\
\hline 2004 & Sudan (Now South Sudan) & Ebola Sudan \\
\hline 2004 & Russia & Ebola Zaire \\
\hline 2004 & Cairns, Australia & Hendra \\
\hline 2004 & Townsville, Australia & Hendra \\
\hline 2004 & Bangladesh & Nipah \\
\hline 2005 & Bangladesh & Nipah \\
\hline 2006 & Peachester, Australia & Hendra \\
\hline 2006 & Muwillumbah, Australia & Hendra \\
\hline 2006 & Bangladesh & Nipah \\
\hline 2007 & DRC & Ebola Zaire \\
\hline 2007 & Clifton Beach, Australia & Hendra \\
\hline 2007 & Peachester, Australia & Hendra \\
\hline 2007 & Bangladesh & Nipah \\
\hline 2008 & Philippines & Ebola Reston \\
\hline 2008 & Proserpine, Australia & Hendra \\
\hline 2008 & Brisbane, Australia & Hendra \\
\hline 2008 & Bangladesh & Nipah \\
\hline 2009 & Bangladesh & Nipah \\
\hline 2010 & Bangladesh & Nipah \\
\hline 2011 & Uganda & Ebola Sudan \\
\hline 2011 & Bangladesh & Nipah \\
\hline 2012 & DRC & Ebola Sudan \\
\hline 2012 & Bangladesh & Nipah \\
\hline 2012 & Jordan & MERS \\
\hline
\end{tabular}


Table 1. Cont.

\begin{tabular}{ccc}
\hline Year & Location & Virus/Strain \\
\hline 2012 & Saudi Arabia & MERS \\
\hline 2013 & West Africa & Ebola Zaire \\
\hline 2013 & Bangladesh & Nipah \\
\hline 2014 & Bangladesh & Nipah \\
\hline 2015 & Bangladesh & Nipah \\
\hline 2015 & Republic of Korea & MERS \\
\hline 2016 & Bangladesh & Nipah \\
\hline 2017 & Bangladesh & Nipah \\
\hline 2018 & DRC & Ebola Bundibugyo \\
\hline 2018 & India & Nipah \\
\hline 2019 & Hunter Valley, Australia & Hendra \\
\hline 2019 & Suhan, China & SARS-Covid 19
\end{tabular}

GAGs are negatively charged, linear polysaccharides including heparin (HP)/heparan sulfate (HS), chondroitin sulfate (CS)/dermatan sulfate (DS), keratan sulfate (KS), and hyaluronic acid (HA) (Figure 1). With the exception of hyaluronic acid, GAGs are covalently linked to core proteins found anchored to animal cell membranes. HA is usually found linked to the cell surface through non-covalent binding to HA-binding proteins such as CD44 and RAHMM [11].

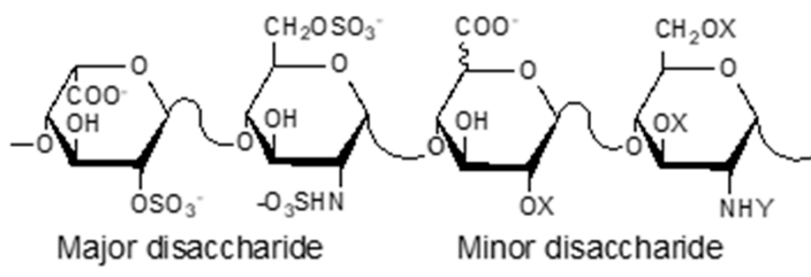

Heparin (HP) $\left(\mathrm{X}=\mathrm{SO}_{3} ; \mathrm{H} ; \mathrm{Y}=\mathrm{SO}_{3} ; \mathrm{COCH}_{3}\right)$

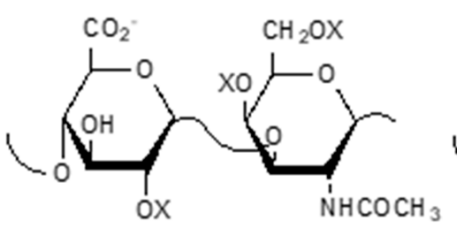

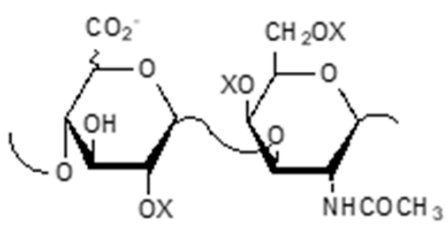

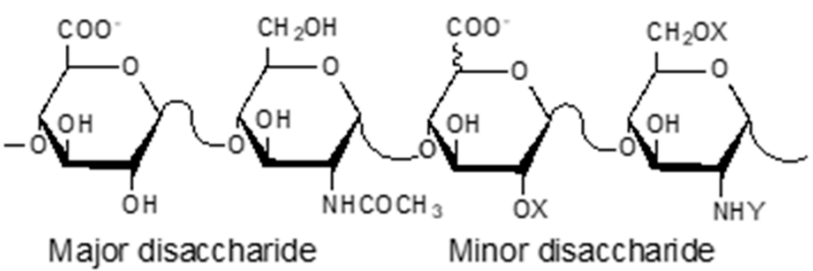

Heparan sulfate (HS) $\left(\mathrm{X}=\mathrm{H}, \mathrm{SO}_{3}-\mathrm{Y}=\mathrm{COCH}_{3}, \mathrm{SO}_{3}^{-}\right)$
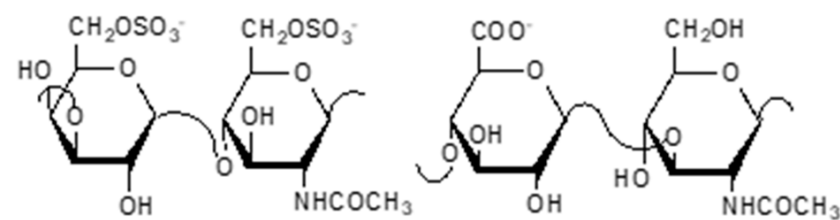

\section{Chondroitin sulfate (CS) Dermatan sulfate (DS) $\left(\mathrm{X}=\mathrm{SO}_{3} ; \mathrm{H}\right)$ Keratan sulfate (KS) Hyaluronic acid (HA)}

Figure 1. Structures of glycosaminoglycans (GAGs).

By interacting with various proteins, GAGs play critical roles in myriad pathological and physiological processes, such as embryonic development, inflammation, cancer, cardiovascular diseases, and infectious diseases. The GAGs, attached to a core protein, comprise proteoglycans found on the host cell surface can serve as co-receptors for pathogens, facilitating specific interactions between host and pathogen during the early stage of infection by bacteria, fungi, viruses, and parasites [12] (Table 2). Recent studies taking place during the COVID-19 pandemic show that the interactions between cellular HS and S-protein of SARS-CoV-2 are critical for viral infection $[13,14]$. Thus, manipulating GAG-protein interactions may lead to effective therapeutic approaches to defending host cells from infection. In this review, we focus on the role of GAGs in the pathogenesis of viral zoonotic diseases. 
Table 2. Common zoonotic viral, bacterial, fungal, and parasitic diseases.

\begin{tabular}{|c|c|c|c|c|c|}
\hline Disease & Pathogen & Animal & Insect Vector & GAG-Binding Protein & Reference \\
\hline \multicolumn{6}{|l|}{ VIRAL } \\
\hline AIDS & HIV Lentivirus & Chimps & None & GP-120 & [15] \\
\hline Bird flu & Influenza A H5N1 & Waterfowl & None & - & - \\
\hline Chikungunya & Alphavirus & & & & [16] \\
\hline Covid/MERS/SARS & Coronavirus & $\begin{array}{c}\text { Bats, } \\
\text { civets/camels }\end{array}$ & None & Spike glycoprotein & {$[11,12]$} \\
\hline Dengue fever & Flavivirus & Monkeys & Mosquito & Envelope protein & \\
\hline Ebola & Filovirus & Bats & None & Filoviral glycoprotein & [17] \\
\hline $\begin{array}{l}\text { Encephalitis from } \\
\text { ticks }\end{array}$ & Flavivirus & & Tick & Envelope protein & [18] \\
\hline Hendra & Hendra Henipavirus & Bats & None & Ephrin-B2 and -B3 & [19] \\
\hline Hepatitis E & Orthohepevirus HEV & Rats & None & ORF2 capsid protein & [20] \\
\hline $\begin{array}{c}\text { Japanese } \\
\text { encephalitis }\end{array}$ & Flavivirus & Bats/pigs & Mosquitos & & \\
\hline Louping ill & Flavivirus & Sheep & Tick & - & - \\
\hline $\begin{array}{l}\text { Lymphocytic } \\
\text { choriomeningitis }\end{array}$ & Arenavirus & Rodents & None & - & - \\
\hline Mayaro & $\begin{array}{l}\text { Alphavirus } \\
\text { Togaviridae }\end{array}$ & Monkeys & Mosquitos & & [21] \\
\hline Nipah & Nipah Henipavirus & Bats & None & Ephrin-B2 and -B3 & [19] \\
\hline Orf infection & Para poxvirus & Sheep & None & - & - \\
\hline Rabies & Lyssavirus & Bats & & Attachment factor & {$[22]$} \\
\hline $\begin{array}{l}\text { Saint Louis } \\
\text { encephalitis }\end{array}$ & Flavivirus & & & & \\
\hline Swine flu & $\begin{array}{c}\text { Virus, Influenza A } \\
\text { H1N1 }\end{array}$ & Swine & None & - & - \\
\hline $\begin{array}{c}\text { Venezuelan equine } \\
\text { encephalitis }\end{array}$ & Alphavirus & & & & \\
\hline West Nile virus & Flavivirus & & Mosquitos & Envelope protein & [23] \\
\hline Yellow fever & Flavivirus & & & & \\
\hline Zika & Flavivirus & Monkeys & Mosquitos & Envelope protein & [24] \\
\hline \multicolumn{6}{|l|}{ BACTERIAL } \\
\hline Anthrax & Bacillus anthracis & $\begin{array}{l}\text { Hoofed } \\
\text { animals }\end{array}$ & None & - & - \\
\hline $\begin{array}{c}\text { Bovine } \\
\text { tuberculosis }\end{array}$ & Mycobacterium bovis & Cattle & None & $\begin{array}{l}\text { Heparin-binding } \\
\text { hemagglutinin }\end{array}$ & {$[25]$} \\
\hline Brucellosis & Brucella sp. & $\begin{array}{l}\text { Cows, goats, } \\
\text { sheep }\end{array}$ & None & Unknown & {$[26]$} \\
\hline $\begin{array}{c}\text { Campylobacter } \\
\text { infection }\end{array}$ & Campylobacter sp. & & None & FliD protein & [27] \\
\hline Cat scratch fever & Bartonella henselae & Cats & None & Pap31 & [28] \\
\hline Erysipeloid & $\begin{array}{l}\text { Erysipelothrix } \\
\text { rhusiopathiae }\end{array}$ & $\begin{array}{l}\text { Fish, birds, } \\
\text { mammals }\end{array}$ & None & - & - \\
\hline Glanders & Burkholderia mallei & & None & - & - \\
\hline
\end{tabular}


Table 2. Cont.

\begin{tabular}{|c|c|c|c|c|c|}
\hline Disease & Pathogen & Animal & Insect Vector & GAG-Binding Protein & Reference \\
\hline Leptospirosis & Leptospira sp. & Cattle & None & LigB adhesin & [29] \\
\hline Listeria infection & $\begin{array}{c}\text { Listeria } \\
\text { monocytogenes }\end{array}$ & $\begin{array}{l}\text { Ruminants, } \\
\text { sheep }\end{array}$ & None & $\begin{array}{c}\text { Surface } \\
\text { protein ActA }\end{array}$ & [30] \\
\hline Lyme disease & Borrelia burgdorferi & Deer & Tick & $\begin{array}{l}\text { OspF-related proteins, } \\
\text { adhesion BBK32, } \\
\text { adhesion DbpA }\end{array}$ & [31] \\
\hline Parrot fever & Chlamydia psittaci & $\begin{array}{l}\text { Parrots and } \\
\text { other birds }\end{array}$ & None & Unknown & [32] \\
\hline Pasteurellosis & Pasteurella multocida & $\begin{array}{l}\text { Domestic } \\
\text { animals }\end{array}$ & None & $\begin{array}{l}\text { OmpA } \beta \text {-barrel ion } \\
\text { channel protein }\end{array}$ & [33] \\
\hline Plague & Yersinia pestis & Rats and rodents & Flea & $\begin{array}{c}\text { Ail outer } \\
\text { membrane protein }\end{array}$ & [34] \\
\hline Q fever & Coxiella burnetii & $\begin{array}{l}\text { Sheep, goats, } \\
\text { cattle }\end{array}$ & None & - & - \\
\hline $\begin{array}{l}\text { Rocky Mountain } \\
\text { spotted fever }\end{array}$ & Rickettsia rickettsii & Rodents, dogs & Tick & Unknown & {$[32]$} \\
\hline Tularemia & Francisella tularensis & Rodents, rabbits & Tick or deerfly & & \\
\hline $\begin{array}{l}\text { Zoonotic } \\
\text { diphtheria }\end{array}$ & $\begin{array}{c}\text { Corynebacterium } \\
\text { diphtheria }\end{array}$ & Dogs & None & - & - \\
\hline \multicolumn{6}{|l|}{ FUNGAL } \\
\hline Ringworm & Tinea corporis & $\begin{array}{l}\text { Domestic animal } \\
\text { species }\end{array}$ & None & - & - \\
\hline \multicolumn{6}{|l|}{ PARASITIC } \\
\hline Cryptosporidiosis & Cryptosporidium sp. & $\begin{array}{l}\text { Calves and } \\
\text { lambs }\end{array}$ & None & $\begin{array}{l}\text { Mucin-like glycoprotein, } \\
\text { CpClec }\end{array}$ & [35] \\
\hline Giardiasis & Giardia lamblia & $\begin{array}{l}\text { Domestic and } \\
\text { wild mammals }\end{array}$ & None & Alpha-11 Giardin Annexin & [36] \\
\hline Malaria & $\begin{array}{l}\text { Plasmodium } \\
\text { falciparum }\end{array}$ & $\begin{array}{l}\text { Nonhuman } \\
\text { primates }\end{array}$ & Mosquito & Circumsporozoite protein & [37] \\
\hline Toxocariasis & $\begin{array}{l}\text { Toxocara canis } \\
\quad \text { or T. cati }\end{array}$ & Dogs/Cats & None & - & - \\
\hline Toxoplasmosis & Toxoplasma gondii & Cats & None & $\begin{array}{l}\text { Protein of } 104 \text { kDa (P104) } \\
\text { Microneme-2 (MIC2) }\end{array}$ & [38] \\
\hline Trichinellosis & Trichinella sp. & Pigs & None & Unknown & [39] \\
\hline
\end{tabular}

\section{Zoonotic Diseases}

\subsection{Filovirus-Ebola}

Ebola virus is a filovirus with a negative RNA structure [6]. There are six distinct species of the Ebola virus, but so far, only Zaire, Reston, Sudan, am Bundibugyo have caused outbreaks in humans (Table 1) [7]. Ebola is classified as a hemorrhagic fever. Marburg is an older, more well-known hemorrhagic fever in the same family as Ebola. Initially, Ebola presents with flu-like symptoms but rapidly progresses with dehydration, hallucinations, and uncontrollable bleeding $[6,40,41]$. This hemorrhaging is how most health care workers, as well as family members, are infected. Quarantine and proper disposal have led to relatively smaller outbreaks occurring every few years since the most common route for infection is person to person through bodily fluids and direct contact [5].

Ebola is a viral hemorrhagic fever originating in Africa. The earliest strain is known as Ebola Zaire. The first outbreak of Ebola Zaire occurred in 1976, known as Zaire (now the 
Democratic Republic of the Congo (DRC)), near the Ebola River. Ebola was 88\% fatal to its victims [42]. Since the initial discovery of the Ebola virus and Ebola virus outbreak in 1976, six distinct strains have been identified, and there have been almost two dozen outbreaks across the globe [5]. Most of these outbreaks centered in South and Central Africa, with a few outbreaks appearing elsewhere (Table 1). Traditional burial rights were changed to avoid contagion spread, and all infected materials were buried or bleached. This allowed all the outbreaks in Central Africa to remain small and isolated [42]

West Africa, however, was not well prepared [42]. The quarantine methods that saved West Africa during smallpox outbreaks were insufficient for containing Ebola, a disease in which the patients are spewing infected material as they die [40]. In the rural parts of Africa, death rites are still practiced that require special care and burial ceremonies for the deceased. These instances in which people must touch the infected corpses led to the large increase in case numbers seen in the infamous West African Ebola outbreak in Sierra Leone from 2013 to 2016, resulting in over 30,000 cases with almost 12,000 fatalities [40,41]. This outbreak led to many new treatment options and preventative measures being tested for Ebola, including the first approved Ebola vaccine in late 2019, but five years later, there is still no effective treatment for this debilitating disease. The West Africa outbreak was the first time that sexual transmission played a major part in the spread of Ebola. Sexual transmission is now thought to be a contributor to one-half of global Ebola flare-ups [43]. A second large outbreak recently occurred from 2018 to 2020 in the DRC with over 3000 cases [36].

The large time gaps in between Ebola outbreaks suggest there is a reservoir host, most likely a mammal, which carries Ebola without becoming symptomatic. Ebola has been found in primates across Africa, but these animals usually expire quickly once infected, so that cannot be the reservoir host [44-46]. As seen in the 1989 Ebola Reston outbreak in the U.S., not all strains of Ebola are fatal in humans, but these are always fatal in nonhuman primates [7]. A typical reservoir animal should not become very ill when infected but instead remain capable of traveling large distances in Africa, causing outbreaks across the continent. One animal that has been implicated as a possible reservoir animal for Ebola is fruit bats. These bats are widely distributed throughout Africa and roost in caves where bodily fluids of one individual are easily transferred to others that leave these bodily fluids throughout Africa where primates and people can come into contact with them [46]. The Kitum cave in Kenya was found to be a source of Marburg in the 1980s when two tourists became ill. However, more recently, bats found in the area of Ebola outbreaks have been traced back to Kitum cave, where all the samples collected from the cave came back positive for Ebola [46].

\subsection{Henipavirus-Hendra and Nipah}

Hendra and Nipah are both paramyxoviruses (genus Henipavirus), but they are very different from the more well-known member of this family, measles [47]. Typical paramyxoviruses such as measles and mumps can be deadly in children but are very rarely serious in the general population. Hendra virus was first seen in 1994 in southern Australia [8]. To date, there have only been seven human cases of Hendra virus infection [48]; however, this disease does pose a serious threat to the horse racing industry [45]. Animals develop fevers, inflammation, bloody froth at the nose and mouth, seizures, and refusal to eat or drink and humans become infected only on close contact. One man died in 1994 after having close contact with several infected horses in his stable. An outbreak in New South Wales in 2019 led to a vaccine for horses being developed, but there are few therapeutic options for infected horses and humans [8].

Humans infected with Nipah show symptoms similar to those observed in Hendra, including inflammation, seizures, respiratory distress, and confusion [9]. Nipah is also a Henipavirus in the paramyxovirus family, which was first found to infect humans and pigs in Malaysia in 1998. Nipah is often fatal in humans but less so in pigs [45]. In the initial outbreak, which spanned from September 1998 to May 1999, there were almost 300 cases in Malaysia with a mortality rate of around $40 \%$ [9]. There have been several outbreaks 
of Nipah across Malaysia, Bangladesh, and India. Overall, the outbreaks in Bangladesh from 2001 to 2015 had around 80\% mortality. The most recent in the southern part of India began in 2018 and has been $91 \%$ fatal [9]. It appears that as time has passed, Nipah has become more fatal. An outbreak in West Bengal was 100\% fatal, but only five people were infected. Animals with Nipah antibodies have been found in Africa, although there have not been any outbreaks in Africa as yet [49]. Nipah is a serious concern to public health in certain regions showing spillover.

Hendra virus infection is most concerning due to its recent appearance in horses in Australia. Horses in recent outbreaks become quite ill, suggesting there may be another animal serving as a reservoir host. Gray-headed flying foxes are fruit bats that live in all of Australia but mostly in Queensland, where the outbreaks began [50]. Flying foxes all across Australia have tested positive for Hendra virus infection but do not become ill [51]. Across Australia, there are also humans who work with bats and are bitten, scratched, and have come into close contact with bat bodily fluids, but these humans do not become sick. Horses are an important intermediate host since only humans in close contact with Hendra-infected horses become ill. Horses can contract the virus from the bats directly, but horses apparently act as amplifiers for the virus, promoting human infection.

Similarly, bats in Asia seem to have always had the Nipah virus in them, but there was no outbreak until 1998. The amplifier host for Nipah appears to be pigs. These pigs can contract the virus by eating fruit and vegetation, which have been contaminated by bodily fluids from the infected bats. Unfortunately, due to limited treatment options in 1998, it was necessary to cull over 1 million pigs to halt the spread of Nipah across Asia. Annual outbreaks in Bangladesh, however, are not due to the pigs; in this case, people ingest fruit and palm sap from trees where infected bats are roosting [51]. Nipah may have required pigs only for the initial crossover, but they are no longer required, making Nipah even more dangerous.

\subsection{Coronavirus-SARS, MERS, and COVID-19}

Severe acute respiratory syndrome (SARS)-coronaviruses (CoV) are named for their halo shape when observed under a microscope (Figure 2). SARS initially spilled over in 2003 in southern China and caused global panic. The severe respiratory symptoms were fatal and very contagious. Over 8000 people were infected, of which over 700 died. The outbreak lasted about one year and then died out. Everyone infected either died or recovered by late 2004. SARS can be spread through the air in sneezes and coughs or through contact with bodily fluids. Once the virus was in humans, it took less than $24 \mathrm{~h}$ for the infection to spread across the ocean to North America. SARS presents in a similar manner as pneumonia and can cause respiratory failure.

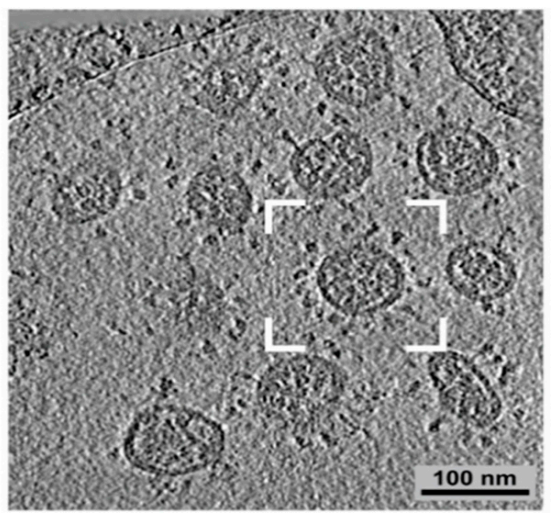

Figure 2. Coronavirus structure under microscope adapted from [52]. SARS-CoV-2 is another coronavirus of concern.

Middle East respiratory syndrome (MERS) was first observed in 2012 in Saudi Arabia and Jordan. Like SARS, observed 9 years earlier, MERS is a coronavirus. MERS was much 
less lethal than SARS, and most people infected with MERS either showed no symptoms or minor cold-like symptoms. MERS-associated deaths were the result of rare cases in which MERS led to pneumonia or kidney failure [10]. Humans become infected with MERS in the same way that humans were infected with Hendra. Instead of caring for sick horses, MERS patients were caring for sick camels who spread the virus in their coughs and sneezes. To date, there have been less than 100 human deaths caused by MERS [53]. Humans usually contract MERS from infected camels, but since camels become ill when infected by the virus, they are probably not the reservoir for MERS.

COVID-19 is caused by severe acute respiratory syndrome-related coronavirus 2 (SARS-CoV-2). The first known case was reported in Wuhan, China, in December 2019. Since COVID-19 transmits easily human-to-human through air contaminated by droplets and small airborne particles, this disease has spread very fast, leading to an ongoing worldwide pandemic. As of October 2021, it has caused over 219 million confirmed COVID19 cases and 4.55 million associated deaths worldwide. In the U.S., one out of 500 residents have died of COVID-19. Older adults and people who have severe underlying medical conditions such as heart or lung disease or diabetes are at higher risk for developing more serious complications from COVID-19 illness. Although we currently have excellent vaccines and a few therapeutics available to fight this disease, it is unknown how long the efficacy of the vaccines can last and how effective the current vaccines are for viral mutants.

The reservoir host for SAR-CoV, MERS, and SARS-CoV-2 are believed to be bats that are found in large numbers throughout the world [45]. Bats have a higher level of interferons present in bats as compared to other animals, including humans. These cytokines, generated by host immune cells, enhance the initial immune response toward infection, promoting rapid viral clearance and persistent infections [54-56]. Moreover, bat lungs are rich in HS GAG capable of coronavirus binding [57]. Thus, in zoonotic infection, bats are believed to be the initial host serving as a viral reservoir.

\subsection{Lentivirus-AIDS}

There are two well-known lentiviruses that infect humans, human immunodeficiency virus (HIV)-1 and HIV-2. While very similar, these are distinct viruses from distinct sources. HIV-2 was discovered after HIV-1 was discovered and was formerly known as simian immunodeficiency virus (SIV) when it was found in monkeys. The main symptoms of HIV-2 in humans appear to be a weakened immune system, diarrhea, and weight loss. HIV-2 cases thus far have all stemmed from people who are infected by close contact with Cerocebus atys, the sooty mangabey, a common gray-colored monkey that inhabits the forests of West Africa, particularly Senegal [45]. HIV-2 is both less infectious and far less lethal than the more virulent lentivirus than HIV-1.

HIV-1 is the virus responsible for acquired immunodeficiency syndrome (AIDS) and the decades-long pandemic [6]. The AIDS epidemic reached global awareness in the 1980s, but spillover is thought to have taken place sometime in the 1970s in Africa. Further research has suggested that the first case of HIV-1 in humans was actually in 1959, involving an English man known only as the Manchester sailor corresponding to the true patient zero [45]. HIV-1 and subsequently AIDS presents with severely lowered T-cell levels as well as overall immune weakness, leading to lethal infection with usually non-lethal bacteria and viruses. A common cold can kill an AIDS patient, and most AIDS patients will die of some type of pneumonia as their bodies cannot fight the infection.

Lentiviruses are not like paramyxoviruses or coronaviruses that can be spread on a sneeze. The exchange of bodily fluids between the infected patient and the non-infected person is required to contract HIV-1 or HIV-2. Blood or other infected fluid needs to enter the bloodstream of the non-infected person for the virus to infect [6]

HIV-1 and HIV-2 are both found naturally in the primates of West and Central Africa. HIV-2 is thought to have evolved from the similar but slightly different SIV, which is common and deadly in primates [58]. When mice carrying human CD4+ T cells and other immune cells are exposed to SIV and bred with or exposed to infected mice, a drastic drop 
in CD4+ T-cell levels is observed in the final generation of mice when compared to the initially infected generation [58]. This suggests that although SIV initially spilled over into humans, it then mutated into the HIV-2 we now see in humans and primates. In contrast, HIV-1 started out in chimpanzees in Central Africa, where it was asymptomatic until people prepared and ate bush meat containing the virus. Since then, HIV-1 has run rampant throughout the human population.

\subsection{Flaviviruses-Dengue, Encephalitis from Ticks, Japanese Encephalitis, Zika}

Flaviviruses are positive single-stranded RNA viruses that commonly pass from ticks and mosquitos to humans [59]. The Flaviviridae family is responsible for dengue fever, tickborne encephalitis, Japanese encephalitis, and Zika virus. All these flaviviruses use GAGs in their initial binding to host cells [60].

Dengue fever is one of the most virulent and lethal diseases carried by mosquitos, with over 20 million cases per year globally [60]. Mild cases of dengue result in high fevers, muscle aches, and fever-induced delirium. Severe cases can cause major hemorrhaging and death, leading to this virus' other name, dengue hemorrhagic fever. Dengue fever passes to humans through a mosquito bite and is commonly found in tropical climates where there is a large mosquito population. Humans are currently the only known reservoir for dengue fever, and it is passed when a mosquito bites an infected individual and within a week bites a second healthy individual in its next blood meal. Although dengue originated in monkeys in Africa, it has been around for centuries, and there are records of human cases as far back as the 1700s. The first human case is believed to have resulted when a mosquito bit an infected monkey and then a human. Despite its origins, dengue almost exclusively infects humans now. Despite this, there is no effective treatment or vaccine for dengue [61]. In 2001 a study to analyze the virus population across the Brazilian amazon showed four different strains of dengue along with many other deadly viruses [62].

Tickborne encephalitis is a severe neurological disorder caused by a flavivirus. Although the initial symptoms are similar to those of the flu (fever, chills, nausea, and vomiting), in most patients, the virus spreads to the central nervous system (CNS) and causes long-lasting neurological damage [63]. With three subtypes (far Eastern, Siberian, and European), tickborne encephalitis can show $20 \%$ fatalities, with the remaining $80 \%$ of infected individuals having long-lasting CNS effects [63]. While there is a vaccine for the European strain, unfortunately, due to climate change and the subsequent uptick in tick population globally, cases are steadily increasing.

Japanese encephalitis is responsible for almost 50,000 deaths per year [64]. Symptoms of Japanese encephalitis mirror tickborne encephalitis with fever, delirium, and muscle pain. Just like tickborne encephalitis, when not fatal, Japanese encephalitis often results in lifelong neurological damage $[65,66]$. Japanese encephalitis played a role in the delayed response to the initial Nipah outbreak in Malaysia. When Nipah originally broke out in pig farmers in Malaysia, it was misdiagnosed as Japanese encephalitis. This is probably due to the similar initial symptoms and the fact that the pigs and bats in Asia are the natural reservoir hosts for Japanese encephalitis [45].

Zika virus was first discovered in humans in 1947, and although it causes very mild symptoms in adults such as fever and rash and in rare cases, infected adults can develop Guillain-Barre syndrome due to Zika infection. The most concerning aspect of Zika infection is the severe birth defects observed in the fetuses of infected pregnant women, and these birth defects prompted the World Health Organization (WHO) to declare Zika a global health concern in 2016 [24]. Zika was originally detected in monkeys in Uganda but has since become a global threat with cases throughout Africa, the Americas, and Asia. Zika, such as dengue, is spread through the bite of an infected mosquito.

\subsection{Orthohepevirus-Hepatitis E}

The first reported human cases of hepatitis E were in India in 1978 [67]. In 1997 hepatitis E was discovered in domestic pigs, confirming its origins as a zoonotic virus. 
Since then, rats have been discovered to be the original carrier of hepatitis E [68]. Hepatitis E can be asymptomatic but typically presents with abdominal pain, nausea, vomiting, and fever, eventually leading to liver failure. Hepatitis $E$ is typically spread by ingesting contaminated drinking water or other poor sanitation situations [69]. Every year there are around 20 million individuals infected with hepatitis E globally [70]. Although rats may have the oldest strain of hepatitis $\mathrm{E}$, the strain that pigs carry is much more likely to cause modern spillovers and subsequent human infections. Approximately $10 \%$ of the pigs in slaughterhouses across the U.S. carry hepatitis E [70]. In addition to pigs and rats, sika deer and nonhuman primates also carry hepatitis E [67].

\subsection{Lyssavirus-Rabies}

Rabies cases have been recorded since $2000 \mathrm{BCE}$, and this single-stranded negative RNA virus is observed globally, with approximately 60,000 human rabies deaths annually [71,72]. Most humans are infected with rabies through the bite of an infected animal, most commonly a dog, although other mammals, including bats and cats, can also transmit the virus to humans. Rabies symptoms include hydrophobia, aerophobia, staggering, confusion, agitation, fever, and foaming at the mouth. Sadly by the time these symptoms are displayed, the virus has progressed beyond the point of recovery [73]. Rabies vaccines, proper containment of infected animals as well as rapid human treatment options have significantly reduced the impact of rabies on society. Even so, rabies remains in the top 10 viral causes of human death [73].

\section{Wet Markets and Bushmeat}

Aside from people infected while caring for sick animals, many of these spillovers are due to a combination of bushmeat and wet markets. Bushmeat is the common name for meat that has been hunted or gathered from the forest/bushland in Africa and Australia [74]. Bushmeat is a staple in many African villages in environments that are not very friendly to farming livestock. Many times, villagers will eat dead bats and primates they either kill or find. This is thought to be how Ebola, HIV, and Lyssa virus initially crossed over. Almost every outbreak in Africa can be traced back to interactions (either eating or skinning) with dead primates and/or bats [46,75]. Consumption of an infected bat started the 2013 Ebola outbreak, which then continued through human-to-human spread. The DRC outbreaks generally stemmed from human consumption or contact with dead chimpanzees and gorillas [74]. The term wet markets is used to describe markets in which live animals are sold for food and either slaughtered on site or immediately after purchase [74]. Asian wet markets have been a source of global controversy for many years for selling live animals for human consumption and have been the cause of many outbreaks [76]. SARS is believed to be initially transferred from bats to another small mammal called a palm civet, which was then eaten. Following the 2003 outbreak, palm civets across China were culled in large numbers as they were thought to be the source of this virus. The involvement of the civet has been brought into question but not before the palm civet population was severely damaged [45]. Wet markets also commonly sell wildlife animals as food. This is often where the infection issue comes to light. These wild animals are taken out of their natural habitat and are kept in small, overcrowded cages with other animals and other species. Bodily fluids of many species mix into the food and water of the animals being sold. Wildlife markets are both an answer to food scarcity, food deserts, and the continuation of traditional recipes. Food deserts in Asia have significantly shrunken in recent decades. Despite this, almost $80 \%$ of consumers choose to buy from wet markets in order to obtain fresher meat or less common meat, such as from reptiles, small rodents, and bats [74,76]. Following the Ebola outbreak in 2013, the WHO came out with an R \& D blueprint that provides a framework for immediate research and response during viral outbreaks [77]. This plan was used during the coronavirus outbreak in 2020. Because of the effectiveness of this plan, two vaccines were developed during the pandemic to prevent further deaths. 


\section{Roles of GAGs in Pathogenesis of Viral Zoonotic Diseases}

4.1. Ebola

Filoviruses such as Ebola need to bind to glycoproteins on host cells to infect [17]. The viral glycoprotein (GP) has two subunits that aid in the infection of host cells. GP1 is responsible for the initial binding of the virion to the host cell, while GP2 is key in membrane fusion between the virion and the host cell [78]. Soluble GAGs such as heparin have shown inhibition of the infection of filoviruses in human cells [79]. Cells treated with heparin in any concentration showed competitive inhibition of viral infection [79]. Using timed addition studies, heparin was found to clearly inhibit GP1 and prevent initial binding to the host cell [78]. Further studies using heparin's effect on viral infection and progression have shown that pretreated cells are significantly less likely to become infected with the Ebola virus. When cells are treated with HP solution, the subsequent exposure to the Ebola virus does not produce infection [80].

\subsection{SARS, MERS, and COVID-19}

SARS-CoV-2, like all coronaviruses, attaches to host cell protein receptors through its spike glycoprotein, and this binding is mediated binding to HS on the surface of the host cells $[5,6]$. SARS-CoV-2 surface is decorated with envelope (E), membrane (M), and spike (S) proteins. A virion lands on the host cell surface by binding to HS proteoglycan (PG). S-protein undergoes proteolytic digestion by host cell surface protease, which initiates viral-host cell membrane fusion by conformational change caused by host cell receptor binding (HSPG and ACE2). ACE2 is an established host cell surface receptor in SARS-CoV2 host cell entry. Virion enters the host cell and further experiences proteolytic processing by endosomal host cell protease $[57,81]$.

SARS-CoV-2 causes respiratory illnesses and shows significant binding to human lung cells, and the most common proteoglycan in the human lung is HS. Therefore treatment with HP results in competitive inhibition of SARS-CoV-2 infection of human lung cells [13]. Most of the studies that have centered on HP and HS and their relation to SARS-CoV-2 infection relied on surface plasmon resonance (SPR) to estimate the amount of HP needed for lung cells to escape infection. The percent inhibition of infection of lung cells is linearly related to the log of HP concentration, and a relatively small amount of heparin is required for $100 \%$ inhibition of infection [82]. Viral infections produce an inflammatory response in the body as the immune system attempts to fight off the infection. As seen in sepsis and other widespread infections, this inflammatory response can lead to increased blood coagulation [83]. HP is an anticoagulant and also shows anti-inflammatory and antiviral activity, suggesting that it may be an excellent candidate for the prophylaxis and treatment of SARS-CoV-2 infection $[81,83]$. In severe cases of SARS-CoV-2, there is a leakage of proteins out of epithelial cells that are normally prevented by heparinase. Heparin can also prevent this by inhibiting heparinase activity in infected individuals [81]. Heparin has also been shown to negate the effects of circulatory histones resulting from viral infections [81].

\subsection{AIDS}

HIV-1 and HIV-2 both bind to the gp120 protein receptors on the surface of human host cells [6]. GAGs offer possible antiviral effects for these infections. HP does not normally bind to host cells, and when radiolabeled HP is introduced to host cells, there is little to no retention of the HP. However, in the presence of HIV-1 significant amounts of radiolabeled $\mathrm{HP}$ are retained on the surface of host cells [15]. These results suggest that HP binds to the glycoproteins on the surface of the viral particles and results in competitive inhibition. Other GAGs, i.e., CS, DS, and GAG mimetics, i.e., dextran sulfate, fucoidan, also are also known to interfere with viral infection. However, only highly sulfated HP and its close relative, HS, effectively prevent the attachment of HIV-1 virions to host cells [15]. Similarly, polyanions inhibiting the gp120 binding in the gut during early SIV and HIV-2 infection largely prevent infection and lead to immune system damage [84]. 


\subsection{Dengue, Encephalitis from Ticks, West Nile Virus, Zika}

Dengue fever, tickborne encephalitis, Japanese encephalitis, West Nile virus, Zika, yellow fever are all caused by viruses are in the same family that are collectively known as flaviviruses. All these viruses are positive RNA-based viruses. They all bind to negatively charged HS and positively charged DC-SIGN receptors on host cells. Negatively charged HP molecules represent ideal competitors for these receptors blocking infection [85].

Like all flaviviruses, dengue virus uses GAGs on the cell surface for initial attachment. This has led to extensive research into the possibility of using GAGs to treat or prevent dengue virus infection. The envelope protein on flavivirus envelopes is the first point of contact between virus cells and host cells [86]. Highly sulfated HP, as well as HP with reduced sulfation, were tested to compare their ability to inhibit the binding of dengue virus to host cells, the highly sulfated HP successfully prevented dengue infection in the test cells [61]. Further studies of the dengue virus have shown that HP binds the envelope protein at residues K291 and K295, blocking viral entry in host cells [87]. Suramin (Figure 1) is a well-known HP mimetic that shows significant inhibition of viral infection [88]. Suramin at various concentrations also shows noncompetitive inhibition of the dengue NS3 helicase with an $\mathrm{IC}_{50}$ of 0.4 [89].

Infections by different flaviviruses are inhibited by GAGs with different structures of chain lengths. Japanese encephalitis can only be inhibited by highly sulfated HP polysaccharides, whereas Zika is best inhibited by HP oligosaccharides [86]. HP inhibits Zika virions binding to host cells. Both sulfated and unsulfated HP do this in a dose-dependent manner. Unlike HP, which only prevents infection in the early stages of virus binding, suramin inhibits every stage of viral infection. As soon as cells are treated with suramin, the current stage of infection, be it binding, fusion, or replication, is halted [85]. The concentration of HS on the host cells exposed to Japanese encephalitis has an impact on the ability of a virus to result in plagues $[90,91]$. When HP chains of different molecular weights were tested for anti-Zika virus activity, a critical chain length could result in effective viral inhibition [92]. Similarly, GAGs have been shown to inhibit tickborne encephalitis virus infection of cell cultures by up to five-fold [93].

\subsection{Hepatitis $E$}

Hepatitis $\mathrm{E}$ has three open reading frames. Open reading frame 2 has been found to control the binding of virion particles to liver cells. Open reading frame 2 preferentially binds to the HS GAG chains of cell surface proteoglycans. This binding led researchers to test the binding compatibility between open reading frame 2 on hepatitis E to HP. When measured against the control protein, there was significant binding to HP. Therefore, $\mathrm{HP}$ might represent a possible antiviral treatment for hepatitis $\mathrm{E}$ through its competitive inhibition of open reading frame 2 binding [20].

\subsection{Rabies}

The virus causing rabies is a negative single-strand RNA virus that uses proteins on the virion to bind to host cell receptors. As with many other negative RNA viruses, HS mediates virion host cell binding, and when neuronal cells are pretreated with HS, the virus is incapable of infecting these pretreated cells [22]. As with many other zoonotic viruses, the more highly sulfated HP has excellent antiviral properties through competitive inhibition of virus binding to the less sulfated HS on the surface of the host cell [22]. An $\mathrm{HP}$ concentration of between 20 and $40 \mu \mathrm{g} / \mathrm{mL}$ shows excellent inhibition of rabies virus as determined using enzyme-linked immunosorbent assay [94].

\section{Potential Prophylactic and Therapeutic Applications of GAGs in the Treatments of Viral Zoonotic Diseases}

GAGs are polysaccharides with anionic, disaccharide repeating units and are found primarily on the surface of host cells [95]. One GAG that has garnered significant interest in antiviral studies is HS. This sulfated polysaccharide inhibits viral binding to host cells 
as well as viral penetration and subsequent infection [95]. The initial penetration stage of virus infection controls the virulency as well as the pathogenicity. This initial stage is mediated by the interaction between surface glycoproteins on the virion and the host cell receptors. As previously discussed, viruses initially bind to host cells by attaching to GAGs. HS, and similar GAGs, also act as mediators for endocytosis in viral infection. Treating virus particles with GAGs has been found to inhibit the binding of the surface glycoproteins to host cells, effectively neutralizing the virus (Figure 3) [93]. As early as the 1960s, studies on HS have shown its potential as antiviral activity. Heparinized blood has also been shown to inhibit infection by GAG-binding pathogens [96].

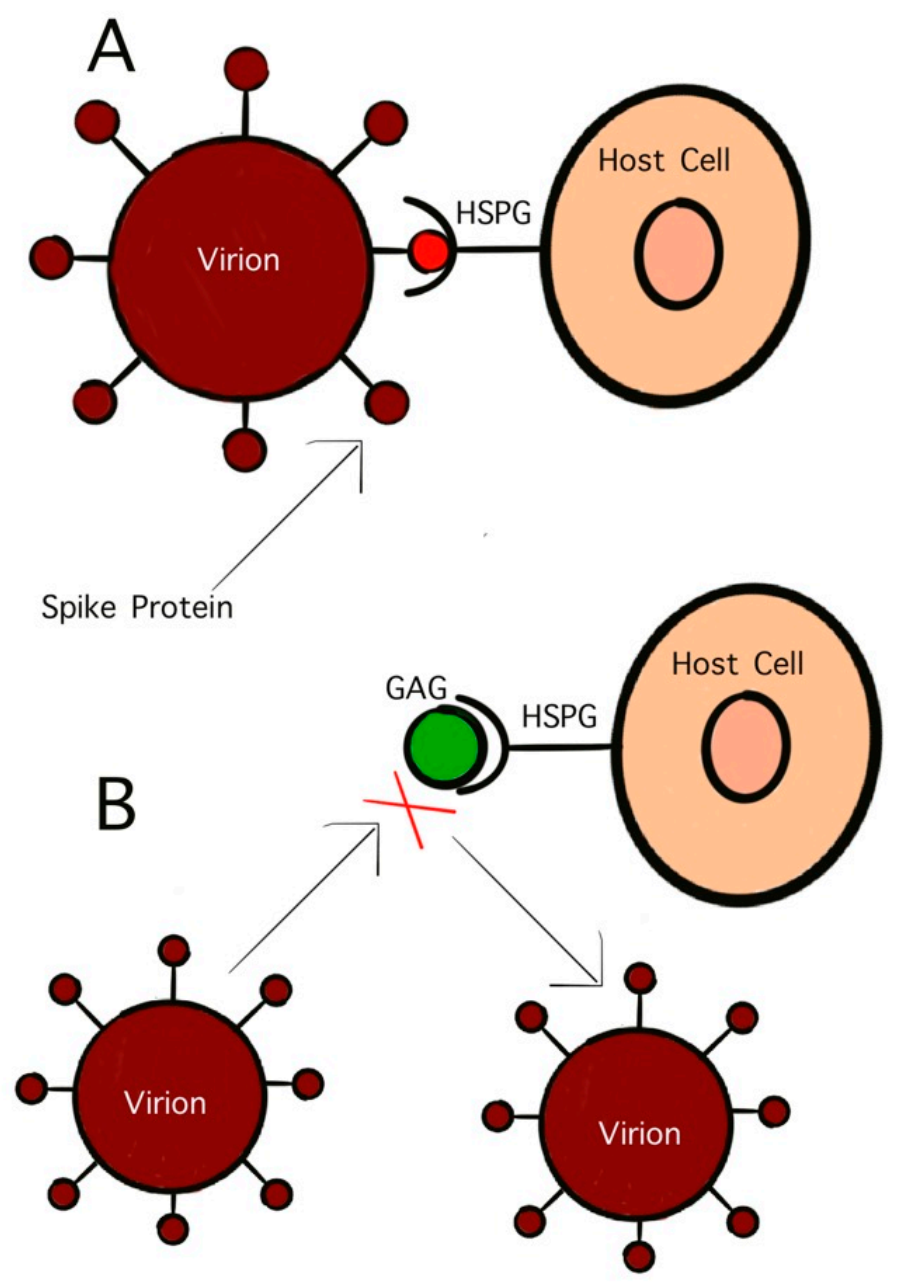

Figure 3. Competitive inhibition of virion binding to host cell receptor by GAGs. (A) Interaction of S-protein with HS on the host cell surface; (B) inhibition of HS mimetic on the interaction of S-protein with HS.

There have been many studies since the 2013 Ebola outbreak concerning the possibility of using glycochemistsy to prevent or treat Ebola virus infection [10]. Among these studies, the consensus has been that the T-cell production by CD8+/CD4+ has a direct relationship with the progression of Ebola infection. When nonhuman primates were exposed to the Ebola virus glycoprotein and subsequently depleted of their CD8+/CD4+ T cells, they became unable to have an immune response and succumbed to illness [10]. Tipton and coworkers mapped the glycopeptide to understand the interaction between glycoproteins present on the Ebola virus surface and the host immune system. GP- 1 and -4 were shown to readily react with samples from Ebola survivors to produce large amounts of interferon gamma, which is an important cytokine produced by antigen-specific CD8+/CD4+ cells to fight infection, meaning these peptides could provide possible vaccine components 
to help the host immune system better cope with Ebola virus exposure [10]. Cai and coworkers tested the possibility of using immunotoxins to prevent or reverse Ebola virus infection. These immunotoxins have been shown to bind to the GP-1, which, as stated above, inhibits the progression of Ebola virus infection in humanized cells as well as nonhuman primates [5]. One of the main symptoms of Ebola infection is the violent widespread hemorrhagic due to poor cell adhesion. This lack of adhesion is caused by glycosylation of the surface glycoprotein. In cells infected with Ebola, where the enzymes are needed for glycolysis, the cell adhesion is unaffected [97]. If this glycolysis could be interrupted, the most common cause of death in Ebola patients (hemorrhage) would be eliminated. Since the 2013 West Africa outbreak Ebola virus has been found in the semen of surviving male Ebola patients [43]. GAGs are inherently nontoxic, making them an ideal candidate for preventative drug discovery. If people in areas where Ebola survivors are living could take GAGs as a preventative measure, this might eliminate the possibility of sexually transmitted Ebola, reducing the chances of another outbreak as the virions would be unable to bind to host cells and cause infection.

Dengue fever is also a hemorrhagic fever characterized by vascular injury and leakage due to an excess of NS1 dengue glycoprotein. NS1 binds to host HS; therefore, exogenously administered HS can mediate dengue infection and possibly be used to treat other hemorrhagic fevers [96]. HP has been avoided because its anticoagulant activity can contribute to hemorrhage but the HP mimetic suramin is currently being used off-label to treat dengue fever [98].

At present, the only treatment options for Hendra and Nipah are supportive therapy to treat the symptom and broad-spectrum antivirals designed for RNA viruses [9]. Based on the above mentioned, these options are insufficient and have been ineffective for preventing the increased mortality of Hendra and Nipah. For paramyxoviruses to infect, they first bind to the host cell and fuse their lipid envelope through the attachment and fusion glycoproteins binding to ephrin receptors on the host cell. Once these are bound, the hydrophobic fusion peptide is inserted into the cell to allow genome release. Measles is a paramyxovirus for which a vaccine is given to most children during infancy. This vaccine uses antibodies specific to the fusion protein on the measles envelope to prevent attachment to the host membrane [49]. In 2019 researchers tested a similar antibody treatment option for both Nipah and Hendra virus in primate and rodent subjects [49]. Treatment with these prefusion anti-fusion protein antibodies inhibited viral infection, reducing post-infection lethality. Ferrets given antibodies specific to the fusion protein avoided infection or, when given several days post infection, were able to recover [99]. This similar result across species speaks of a high likelihood of possible human analogs.

$\mathrm{HP}$ is a well-known blood thinner that activates antithrombin to prevent blood clots in humans and animals [19]. As with many other virus particles, Hendra and Nipah bind to HS on the surface of host cells. When heparin was added before and after exposure to Hendra and Nipah virus, HP showed competitive inhibition of Hendra and Nipah virus both [19]. When HP binds to the HS receptors on host cells, there is no or limited ability for Hendra and Nipah to show trans infection between host cells [19]

Hendra and Nipah are in the same family and genus but are distinctly different viruses (Figure 4). Although their glycoproteins seem to react similarly when treated with antibodies specific to the fusion protein, it should be noted that these studies all use anti-Hendra fusion protein antibodies against Hendra and antibodies specific to the fusion protein against Nipah [100]. Researchers discovered that the G protein is more important to Nipah infection than its fusion protein, whereas the fusion protein in Hendra is the main component of membrane attachment [100]. Molecular docking studies have been used to find common peptides that may inhibit the binding of glycoproteins on the surface of the Nipah virus [101]. Naturally occurring human antibodies have also been found to inhibit Hendra when given to infected animals [102]; interestingly, some of these monoclonal antibodies that neutralize Hendra also inhibit Nipah infection, with less reliability [102]. 


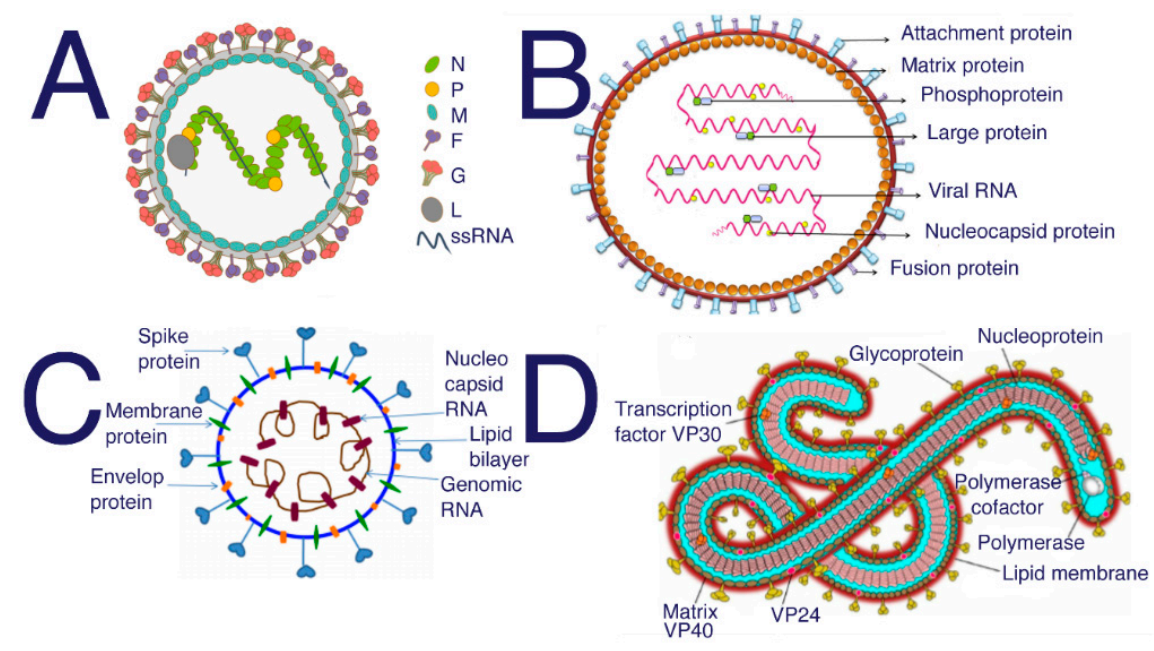

Figure 4. Structure of (A) Nipah from [103] (B) Hendra [104] (C) SARS-CoV-2 [105] (D) Ebola [106]. SARS, SARS-CoV-2, and MERS all require HS to act as a coreceptor in order to bind to host cells $[5,6,48]$. Many studies have been performed to investigate the inhibitory properties of HS against SARS and SARS-CoV-2. These studies have shown that sulfated polysaccharides exhibit similar inhibition [14]. Suramin is typically used as an antiparasitic treatment in humans; however, suramin shows significant inhibition of SAR-CoV-2 infection [107].

Sulfated marine glycans have shown a wide range of medical applications, including antiviral activity [108]. Since the natural host cell receptor, HS is a sulfated GAG using sulfated marine glycans as an antiviral treatment should inhibit virus binding. Sulfated glycans from marine sources have been found to effectively inhibit adenovirus in humanized cells [109]. Since Ebola, Hendra, and Nipah all use glycoproteins on their cell surface to bind to host membranes, these marine sulfated glycans could be a natural antiviral treatment option for these diseases. Rabies virus is inhibited by carrageenan, a sulfated marine glycan found in red seaweed [110].

\section{Conclusions and Future Perspective}

Zoonotic spillovers have only become more frequent over time, with approximately one in the year globally. The most recent outbreak of SARS-CoV-2 sparked a global pandemic on the same scale as the Spanish influenza pandemic. The increased frequency is due to many factors. The changing habitat of infected animals is being changed by climate change as well as human expansion. Additionally, the increasing world population and the subsequently increased need for food animals are encroaching on wild animal habitats and numbers at unprecedented rates. The strain that humans place on ecosystems is being felt globally. When these strains are not well managed, spillovers occur [62].

Eliminating wet markets, limiting bushmeat consumption, and habitat preservation can only do so much. Humans will continue to come into contact with infected animals, and spillovers will continue to occur. In conjunction with conservation efforts, research is required to better understand zoonotic diseases as well as new options for prevention and treatment.

HP and other GAGs could provide these options. HP has shown great promise as a prophylactic antiviral treatment [111]. With HP's antiviral, anti-inflammatory and competitive binding to host cells, HP could be the next big antiviral treatment or prophylactic. HP is not the only GAG that has shown impressive activity in relation to SARS-CoV-2 treatment, low molecular weight HP, enoxaparin, showed a lower mortality rate with similar benefits $\mathrm{HP}$ in the treatment of SARS-CoV-2 patients [112]. Coronaviruses, filoviruses, flaviviruses, lentiviruses, and Henipavirus cause some of the most debilitating human diseases. The data already collected show that HP, suramin, or similar compounds have the potential to mediate if not eliminate these viruses in the human population. 
Glycochemistsy has progressed greatly in recent years, along with GAG research, and recently, glyconanoparticles have been tested for antiviral activity [113]. Perhaps by coating the traditional gold and silver core nanoparticles or origami DNA nanoparticles with GAGs, an improved antiviral approach might be possible. For example, AuNPs have been shown to prevent binding at the DC-SIGN receptor, while HP prevents the binding of viral spike proteins to the HS receptors on host cells. Thus, coating the AuNPs with HP might inhibit binding at both the DC-Sign receptor and the HS receptor, effectively preventing viral infection.

GAGs are sulfated polysaccharide chains, so it stands to reason that other polysaccharides, having similar structures and sulfation content, might also provide similar results. Sulfated polysaccharides such as fucoidan are readily available in seaweed globally and could provide another treatment option [108]. GAGs and their derivatives (some of which have low or no anticoagulant activity) could represent a class of antiviral drugs against a myriad of viruses.

Author Contributions: Reference search and writing: S.B.; Revision and writing: F.Z. and R.J.L. All authors have read and agreed to the published version of the manuscript.

Funding: This research received no external funding.

Institutional Review Board Statement: Not applicable.

Informed Consent Statement: Not applicable.

Data Availability Statement: Not applicable.

Conflicts of Interest: The authors declare no conflict of interest.

\section{References}

1. Royce, K.; Fu, F. Mathematically Modeling Spillovers of an Emerging Infectious Zoonosis with an Intermediate Host. PLoS ONE 2020, 15, e0237780. [CrossRef]

2. Beran, G.W. Handbook of Zoonoses, Section A: Bacterial, Rickettsial, Chalamydial, and Mycotic; Handbook of Zoonoses, Section B: Viral, 2nd ed.; CRC Press: Boca Raton, FL, USA, 1994.

3. Lei, R.; Qiu, R. A Strategy to Prevent and Control Zoonoses? Hastings Cent. Rep. 2020, 50, 73-74. [CrossRef]

4. Santana, C. COVID-19, Other Zoonotic Diseases and Wildlife Conservation. Hist. Philos. Life Sci. 2020, 42, 45. [CrossRef]

5. Cai, Y.; Yu, S.; Chi, X.; Radoshitzky, S.R.; Kuhn, J.H.; Berger, E.A. An Immunotoxin Targeting Ebola Virus Glycoprotein Inhibits Ebola Virus Production from Infected Cells. PLoS ONE 2021, 16, e0245024. [CrossRef] [PubMed]

6. Sompayrac, L.; Sompayrac, L. How Pathogenic Viruses Think: Making Sense of Virology, 2nd ed.; Jones \& Bartlett Learning: Burlington, MA, USA, 2013; ISBN 978-1-4496-4580-9.

7. Escudero-Pérez, B.; Ruibal, P.; Rottstegge, M.; Lüdtke, A.; Port, J.R.; Hartmann, K.; Gómez-Medina, S.; Müller-Guhl, J.; Nelson, E.V.; Krasemann, S.; et al. Comparative Pathogenesis of Ebola Virus and Reston Virus Infection in Humanized Mice. JCI Insight 2019, 4, e126070. [CrossRef] [PubMed]

8. Williamson, K.M.; Wheeler, S.; Kerr, J.; Bennett, J.; Freeman, P.; Kohlhagen, J.; Peel, A.J.; Eby, P.; Merritt, T.; Housen, T.; et al. Hendra in the Hunter Valley. One Health 2020, 10, 100162. [CrossRef] [PubMed]

9. Soman Pillai, V.; Krishna, G.; Valiya Veettil, M. Nipah Virus: Past Outbreaks and Future Containment. Viruses 2020, 12, 465. [CrossRef]

10. Harmon, A. Middle East Respiratory Syndrome; Salem Press Encycl. Health: Hackensack, NJ, USA, 2020.

11. Misra, S.; Hascall, V.C.; Markwald, R.R.; Ghatak, S. Interactions between Hyaluronan and Its Receptors (CD44, RHAMM) Regulate the Activities of Inflammation and Cancer. Front. Immunol. 2015, 6, 201. [CrossRef]

12. Wadstrom, T.; Ljungh, A. Glycosaminoglycan-Binding Microbial Proteins in Tissue Adhesion and Invasion: Key Events in Microbial Pathogenicity. J. Med. Microbiol. 1999, 48, 223-233. [CrossRef]

13. Kim, S.Y.; Jin, W.; Sood, A.; Montgomery, D.W.; Grant, O.C.; Fuster, M.M.; Fu, L.; Dordick, J.S.; Woods, R.J.; Zhang, F.; et al. Characterization of Heparin and Severe Acute Respiratory Syndrome-Related Coronavirus 2 (SARS-CoV-2) Spike Glycoprotein Binding Interactions. Antiviral Res. 2020, 181, 104873. [CrossRef]

14. Clausen, T.M.; Sandoval, D.R.; Spliid, C.B.; Pihl, J.; Perrett, H.R.; Painter, C.D.; Narayanan, A.; Majowicz, S.A.; Kwong, E.M.; McVicar, R.N.; et al. SARS-CoV-2 Infection Depends on Cellular Heparan Sulfate and ACE2. Cell 2020, 183, 1043-1057. [CrossRef]

15. Harrop, H.A.; Rider, C.C. Heparin and Its Derivatives Bind to HIV-1 Recombinant Envelope Glycoproteins, Rather than to Recombinant HIV-1 Receptor, CD4. Glycobiology 1998, 8, 131-137. [CrossRef] [PubMed]

16. Figueiredo, L.T.M. Emergent Arboviruses in Brazil. Rev. Soc. Bras. Med. Trop. 2007, 40, 224-229. [CrossRef] 
17. O'Hearn, A.; Wang, M.; Cheng, H.; Lear-Rooney, C.M.; Koning, K.; Rumschlag-Booms, E.; Varhegyi, E.; Olinger, G.; Rong, L. Role of EXT1 and Glycosaminoglycans in the Early Stage of Filovirus Entry. J. Virol. 2015, 89, 5441-5449. [CrossRef] [PubMed]

18. Kozlovskaya, L.I.; Osolodkin, D.I.; Shevtsova, A.S.; Romanova, L.I.; Rogova, Y.V.; Dzhivanian, T.I.; Lyapustin, V.N.; Pivanova, G.P.; Gmyl, A.P.; Palyulin, V.A.; et al. GAG-Binding Variants of Tick-Borne Encephalitis Virus. Virology 2010, 398, 262-272. [CrossRef] [PubMed]

19. Mathieu, C.; Dhondt, K.P.; Châlons, M.; Mély, S.; Raoul, H.; Negre, D.; Cosset, F.-L.; Gerlier, D.; Vivès, R.R.; Horvat, B. Heparan Sulfate-Dependent Enhancement of Henipavirus Infection. mBio 2015, 6, e02427. [CrossRef] [PubMed]

20. Kalia, M.; Chandra, V.; Rahman, S.A.; Sehgal, D.; Jameel, S. Heparan Sulfate Proteoglycans Are Required for Cellular Binding of the Hepatitis E Virus ORF2 Capsid Protein and for Viral Infection. J. Virol. 2009, 83, 12714-12724. [CrossRef] [PubMed]

21. Pinheiro, F.P.; Freitas, R.B.; Travassos da Rosa, J.F.; Gabbay, Y.B.; Mello, W.A.; LeDuc, J.W. An Outbreak of Mayaro Virus Disease in Belterra, Brazil. I. Clinical and Virological Findings. Am. J. Trop. Med. Hyg. 1981, 30, 674-681. [CrossRef]

22. Sasaki, M.; Anindita, P.D.; Ito, N.; Sugiyama, M.; Carr, M.; Fukuhara, H.; Ose, T.; Maenaka, K.; Takada, A.; Hall, W.W.; et al. The Role of Heparan Sulfate Proteoglycans as an Attachment Factor for Rabies Virus Entry and Infection. J. Infect. Dis. 2018, 217, 1740-1749. [CrossRef]

23. Lee, E.; Hall, R.A.; Lobigs, M. Common E Protein Determinants for Attenuation of Glycosaminoglycan-Binding Variants of Japanese Encephalitis and West Nile Viruses. J. Virol. 2004, 78, 8271-8280. [CrossRef]

24. Kim, S.Y.; Zhao, J.; Liu, X.; Fraser, K.; Lin, L.; Zhang, X.; Zhang, F.; Dordick, J.S.; Linhardt, R.J. Interaction of Zika Virus Envelope Protein with Glycosaminoglycans. Biochemistry 2017, 56, 1151-1162. [CrossRef]

25. Menozzi, F.D.; Bischoff, R.; Fort, E.; Brennan, M.J.; Locht, C. Molecular Characterization of the Mycobacterial Heparin-Binding Hemagglutinin, a Mycobacterial Adhesin. Proc. Natl. Acad. Sci. USA 1998, 95, 12625-12630. [CrossRef] [PubMed]

26. Castaneda-Roldan, E.I.; Avelino-Flores, F.; Dall'Agnol, M.; Freer, E.; Cedillo, L.; Dornand, J.; Giron, J.A. Adherence of Brucella to Human Epithelial Cells and Macrophages Is Mediated by Sialic Acid Residues. Cell. Microbiol. 2004, 6, 435-445. [CrossRef] [PubMed]

27. Freitag, C.M.; Strijbis, K.; van Putten, J.P.M. Host Cell Binding of the Flagellar Tip Protein of Campylobacter jejuni. Cell. Microbiol. 2017, 19, e12714. [CrossRef] [PubMed]

28. Dabo, S.M.; Confer, A.W.; Anderson, B.E.; Gupta, S. Bartonella Henselae Pap31, an Extracellular Matrix Adhesin, Binds the Fibronectin Repeat $\mathrm{III}_{13}$ Module. Infect. Immun. 2006, 74, 2513-2521. [CrossRef]

29. Ching, A.T.C.; Fávaro, R.D.; Lima, S.S.; Chaves, A.d.A.M.; de Lima, M.A.; Nader, H.B.; Abreu, P.A.E.; Ho, P.L. Lepstospira Interrogans Shotgun Phage Display Identified LigB as a Heparin-Binding Protein. Biochem. Biophys. Res. Commun. 2012, 427, 774-779. [CrossRef]

30. Alvarez-Domínguez, C.; Vázquez-Boland, J.A.; Carrasco-Marín, E.; López-Mato, P.; Leyva-Cobián, F. Host Cell Heparan Sulfate Proteoglycans Mediate Attachment and Entry of Listeria Monocytogenes, and the Listerial Surface Protein ActA Is Involved in Heparan Sulfate Receptor Recognition. Infect. Immun. 1997, 65, 78-88. [CrossRef]

31. Lin, Y.-P.; Bhowmick, R.; Coburn, J.; Leong, J.M. Host Cell Heparan Sulfate Glycosaminoglycans Are Ligands for OspF-Related Proteins of the Lyme Disease Spirochete: GAG Binding by B. Burgdorferi OspF-Related Proteins. Cell. Microbiol. 2015, 17, 1464-1476. [CrossRef]

32. Rostand, K.S.; Esko, J.D. Microbial Adherence to and Invasion through Proteoglycans. Infect. Immun. 1997, 65, 1-8. [CrossRef]

33. Harper, M.; Boyce, J.D.; Adler, B. Pasteurella Multocida Pathogenesis: 125 Years after Pasteur: Pasteurella Multocida Pathogenesis. FEMS Microbiol. Lett. 2006, 265, 1-10. [CrossRef]

34. Yamashita, S.; Lukacik, P.; Barnard, T.J.; Noinaj, N.; Felek, S.; Tsang, T.M.; Krukonis, E.S.; Hinnebusch, B.J.; Buchanan, S.K. Structural Insights into Ail-Mediated Adhesion in Yersinia Pestis. Structure 2011, 19, 1672-1682. [CrossRef]

35. Ludington, J.G.; Ward, H.D. The Cryptosporidium Parvum C-Type Lectin CpClec Mediates Infection of Intestinal Epithelial Cells via Interactions with Sulfated Proteoglycans. Infect. Immun. 2016, 84, 1593-1602. [CrossRef]

36. Pathuri, P.; Nguyen, E.T.; Svärd, S.G.; Luecke, H. Apo and Calcium-Bound Crystal Structures of Alpha-11 Giardin, an Unusual Annexin from Giardia Lamblia. J. Mol. Biol. 2007, 368, 493-508. [CrossRef]

37. Sinnis, P.; Coppi, A.; Toida, T.; Toyoda, H.; Kinoshita-Toyoda, A.; Xie, J.; Kemp, M.M.; Linhardt, R.J. Mosquito Heparan Sulfate and Its Potential Role in Malaria Infection and Transmission. J. Biol. Chem. 2007, 282, 25376-25384. [CrossRef]

38. Gong, H.; Kobayashi, K.; Sugi, T.; Takemae, H.; Kurokawa, H.; Horimoto, T.; Akashi, H.; Kato, K. A Novel PAN/Apple Domain-Containing Protein from Toxoplasma Gondii: Characterization and Receptor Identification. PLoS ONE 2012, 7, e30169. [CrossRef] [PubMed]

39. Roy, A.; Sawesi, O.; Pettersson, U.; Dagälv, A.; Kjellén, L.; Lundén, A.; Åbrink, M. Serglycin Proteoglycans Limit Enteropathy in Trichinella Spiralis-Infected Mice. BMC Immunol. 2016, 17, 15. [CrossRef] [PubMed]

40. Preston, R. Crisis in the Red Zone: The Story of the Deadliest Ebola Outbreak in History, and of the Viruses to Come; Random House: New York, NY, USA, 2019.

41. Tipton, T.R.W.; Hall, Y.; Bore, J.A.; White, A.; Sibley, L.S.; Sarfas, C.; Yuki, Y.; Martin, M.; Longet, S.; Mellors, J.; et al. Characterisation of the T-Cell Response to Ebola Virus Glycoprotein amongst Survivors of the 2013-16 West Africa Epidemic. Nat. Commun. 2021, 12, 1153. [CrossRef] [PubMed]

42. Oldstone, M.B.A.; Oldstone, M.R. Ebola's Curse: 2013-2016 Outbreak in West Africa; Academic Press: London, UK, 2017; ISBN 978-0-12-813889-2. 
43. Escaffre, O.; Juelich, T.L.; Freiberg, A.N. Polyphenylene Carboxymethylene (PPCM) in Vitro Antiviral Efficacy against Ebola Virus in the Context of a Sexually Transmitted Infection. Antiviral Res. 2019, 170, 104567. [CrossRef]

44. Coltart, C.E.M.; Lindsey, B.; Ghinai, I.; Johnson, A.M.; Heymann, D.L. The Ebola Outbreak, 2013-2016: Old Lessons for New Epidemics. Philos. Trans. R. Soc. B Biol. Sci. 2017, 372, 20160297. [CrossRef] [PubMed]

45. Quammen, D. Spillover: Animal Infections and the Next Human Pandemic, 1st ed.; W.W. Norton \& Co.: New York, NY, USA, 2012; ISBN 978-0-393-06680-7.

46. Preston, R. The Hot Zone, 1st ed.; Random House: New York, NY, USA, 1994; ISBN 0-679-43094-6.

47. Prasad, A.N.; Woolsey, C.; Geisbert, J.B.; Agans, K.N.; Borisevich, V.; Deer, D.J.; Mire, C.E.; Cross, R.W.; Fenton, K.A.; Broder, C.C.; et al. Resistance of Cynomolgus Monkeys to Nipah and Hendra Virus Disease Is Associated With Cell-Mediated and Humoral Immunity. J. Infect. Dis. 2020, 221, S436-S447. [CrossRef] [PubMed]

48. World Health Organization Hendra Virus Infection. Available online: https://www.who.int/health-topics/hendra-virusdisease\#tab=tab_1 (accessed on 13 October 2021).

49. Dang, H.V.; Chan, Y.-P.; Park, Y.-J.; Snijder, J.; Da Silva, S.C.; Vu, B.; Yan, L.; Feng, Y.-R.; Rockx, B.; Geisbert, T.W.; et al. An Antibody against the F Glycoprotein Inhibits Nipah and Hendra Virus Infections. Nat. Struct. Mol. Biol. 2019, 26, 980-987. [CrossRef] [PubMed]

50. Boardman, W.S.J.; Baker, M.L.; Boyd, V.; Crameri, G.; Peck, G.R.; Reardon, T.; Smith, I.G.; Caraguel, C.G.B.; Prowse, T.A.A. Seroprevalence of Three Paramyxoviruses; Hendra Virus, Tioman Virus, Cedar Virus and a Rhabdovirus, Australian Bat Lyssavirus, in a Range Expanding Fruit Bat, the Grey-Headed Flying Fox (Pteropus Poliocephalus). PLoS ONE 2020, 15, e0232339. [CrossRef] [PubMed]

51. Woon, A.P.; Boyd, V.; Todd, S.; Smith, I.; Klein, R.; Woodhouse, I.B.; Riddell, S.; Crameri, G.; Bingham, J.; Wang, L.-F.; et al. Acute Experimental Infection of Bats and Ferrets with Hendra Virus: Insights into the Early Host Response of the Reservoir Host and Susceptible Model Species. PLoS Pathog. 2020, 16, e1008412. [CrossRef] [PubMed]

52. Yao, H.; Song, Y.; Chen, Y.; Wu, N.; Xu, J.; Sun, C.; Zhang, J.; Weng, T.; Zhang, Z.; Wu, Z.; et al. Molecular Architecture of the SARS-CoV-2 Virus. Cell 2020, 183, 730-738.e13. [CrossRef] [PubMed]

53. Hawkes, N. MERS Coronovirus Has Probably Been Present in Bats for Many Years, Research Shows. BMJ 2013, 347 , f6141. [CrossRef] [PubMed]

54. Brook, C.E.; Boots, M.; Chandran, K.; Dobson, A.P.; Drosten, C.; Graham, A.L.; Grenfell, B.T.; Müller, M.A.; Ng, M.; Wang, L.-F.; et al. Accelerated Viral Dynamics in Bat Cell Lines, with Implications for Zoonotic Emergence. eLife 2020, 9, e48401. [CrossRef]

55. Pavlovich, S.S.; Lovett, S.P.; Koroleva, G.; Guito, J.C.; Arnold, C.E.; Nagle, E.R.; Kulcsar, K.; Lee, A.; Thibaud-Nissen, F.; Hume, A.J.; et al. The Egyptian Rousette Genome Reveals Unexpected Features of Bat Antiviral Immunity. Cell 2018, 173, 1098-1110.e18. [CrossRef]

56. Schountz, T.; Baker, M.L.; Butler, J.; Munster, V. Immunological Control of Viral Infections in Bats and the Emergence of Viruses Highly Pathogenic to Humans. Front. Immunol. 2017, 8, 1098. [CrossRef]

57. Yan, L.; Song, Y.; Xia, K.; He, P.; Zhang, F.; Chen, S.; Pouliot, R.; Weiss, D.J.; Tandon, R.; Bates, J.T.; et al. Heparan Sulfates from Bat and Human Lung and Their Binding to the Spike Protein of SARS-CoV-2 Virus. Carbohydr. Polym. 2021, 260, 117797. [CrossRef]

58. Schmitt, K.; Curlin, J.; Kumar, D.M.; Remling-Mulder, L.; Feely, S.; Stenglein, M.; O'Connor, S.; Marx, P.; Akkina, R. SIV Progenitor Evolution toward HIV: A Humanized Mouse Surrogate Model for SIVsm Adaptation toward HIV-2. J. Med. Primatol. 2018, 47, 298-301. [CrossRef]

59. Flaviviridae_Viral Hemorrhagic Fevers (VHFs). Available online: https://www.cdc.gov/vhf/virus-families/flaviviridae.html (accessed on 13 October 2021).

60. Kim, S.Y. Glycosaminoglycans in Infectious Diseases. Available online: https://onlinelibrary.wiley.com/doi/abs/10.1111/brv.12 034 (accessed on 13 October 2021).

61. Chen, Y.; Maguire, T.; Hileman, R.E.; Fromm, J.R.; Esko, J.D.; Linhardt, R.J.; Marks, R.M. Dengue Virus Infectivity Depends on Envelope Protein Binding to Target Cell Heparan Sulfate. Nat. Med. 1997, 3, 866-871. [CrossRef] [PubMed]

62. Vasconcelos, P.F.C.; Travassos da Rosa, A.P.A.; Rodrigues, S.G.; Travassos da Rosa, E.S.; Dégallier, N.; Travassos da Rosa, J.F.S. Inadequate Management of Natural Ecosystem in the Brazilian Amazon Region Results in the Emergence and Reemergence of Arboviruses. Cad. Saúde Pública 2001, 17, S155-S164. [CrossRef]

63. Akaberi, D.; Båhlström, A.; Chinthakindi, P.K.; Nyman, T.; Sandström, A.; Järhult, J.D.; Palanisamy, N.; Lundkvist, Å.; Lennerstrand, J. Targeting the NS2B-NS3 Protease of Tick-Borne Encephalitis Virus with Pan-Flaviviral Protease Inhibitors. Antiviral Res. 2021, 190, 105074. [CrossRef] [PubMed]

64. Thongtan, T.; Cheepsunthorn, P.; Chaiworakul, V.; Rattanarungsan, C.; Wikan, N.; Smith, D.R. Highly Permissive Infection of Microglial Cells by Japanese Encephalitis Virus: A Possible Role as a Viral Reservoir. Microbes Infect. 2010, 12, 37-45. [CrossRef] [PubMed]

65. Deng, X.; Yan, R.; Li, Z.; Tang, X.; Zhou, Y.; He, H. Economic and Disease Burden of Japanese Encephalitis in Zhejiang Province, 2013-2018. PLoS Negl. Trop. Dis. 2021, 15, e0009505. [CrossRef]

66. Su, Q.; Xie, Z.-X.; He, F.; Liu, Z.-C.; Song, X.-J.; Zhao, F.-C.; Li, D.; Che, F.-Y. Adults with Severe Japanese Encephalitis: A Retrospective Analysis of 9 Cases in Linyi, China. Neurol. Sci. 2021, 42, 2811-2817. [CrossRef]

67. Syed, S.F.; Zhao, Q.; Umer, M.; Alagawany, M.; Ujjan, I.A.; Soomro, F.; Bangulzai, N.; Baloch, A.H.; Abd El-Hack, M.; Zhou, E.-M.; et al. Past, Present and Future of Hepatitis E Virus Infection: Zoonotic Perspectives. Microb. Pathog. 2018, 119, 103-108. [CrossRef] 
68. Reuter, G.; Boros, Á.; Pankovics, P. Review of Hepatitis E Virus in Rats: Evident Risk of Species Orthohepevirus C to Human Zoonotic Infection and Disease. Viruses 2020, 12, 1148. [CrossRef] [PubMed]

69. Hepatitis E Questions and Answers for Health Professionals. Available online: https://www.cdc.gov/hepatitis/hev/hevfaq.htm (accessed on 13 October 2021).

70. Wang, B.; Meng, X.-J. Hepatitis E Virus: Host Tropism and Zoonotic Infection. Curr. Opin. Microbiol. 2021, 59, 8-15. [CrossRef]

71. Hatami, H. History of Rabies in Traditional Medicine's Resources and Iranian Research Studies: On the CccasiOn of the World Rabies Day (September 28, 2012). Int. J. Prev. Med. 2012, 3, 593-595.

72. Reddy, R.V.C.; Mohana Subramanian, B.; Surendra, K.S.N.L.; Babu, R.P.A.; Rana, S.K.; Manjari, K.S.; Srinivasan, V.A. Rabies Virus Isolates of India-Simultaneous Existence of Two Distinct Evolutionary Lineages. Infect. Genet. Evol. 2014, 27, 163-172. [CrossRef]

73. Williamson, J.G. Rabies: Symptoms, Treatment and Prevention; Virology Research Progress series; Nova Science Publishers: Hauppauge, NY, USA, 2010; ISBN 978-1-61122-332-3.

74. Magouras, I.; Brookes, V.J.; Jori, F.; Martin, A.; Pfeiffer, D.U.; Dürr, S. Emerging Zoonotic Diseases: Should We Rethink the Animal-Human Interface? Front. Vet. Sci. 2020, 7, 582743. [CrossRef] [PubMed]

75. Saylors, K.E.; Mouiche, M.M.; Lucas, A.; McIver, D.J.; Matsida, A.; Clary, C.; Maptue, V.T.; Euren, J.D.; LeBreton, M.; Tamoufe, U. Market Characteristics and Zoonotic Disease Risk Perception in Cameroon Bushmeat Markets. Soc. Sci. Med. 2021, 268, 113358. [CrossRef]

76. Naguib, M.M.; Li, R.; Ling, J.; Grace, D.; Nguyen-Viet, H.; Lindahl, J.F. Live and Wet Markets: Food Access versus the Risk of Disease Emergence. Trends Microbiol. 2021, S0966842X21000433. [CrossRef] [PubMed]

77. Kieny, M.P.; Salama, P. WHO R\&D Blueprint: A Global Coordination Mechanism for R\&D Preparedness. Lancet 2017, 389, 2469-2470. [CrossRef] [PubMed]

78. Cheng, H.; Lear-Rooney, C.M.; Johansen, L.; Varhegyi, E.; Chen, Z.W.; Olinger, G.G.; Rong, L. Inhibition of Ebola and Marburg Virus Entry by G Protein-Coupled Receptor Antagonists. J. Virol. 2015, 89, 9932-9938. [CrossRef] [PubMed]

79. Salvador, B.; Sexton, N.R.; Carrion, R.; Nunneley, J.; Patterson, J.L.; Steffen, I.; Lu, K.; Muench, M.O.; Lembo, D.; Simmons, G. Filoviruses Utilize Glycosaminoglycans for Their Attachment to Target Cells. J. Virol. 2013, 87, 3295-3304. [CrossRef]

80. Tamhankar, M.; Gerhardt, D.M.; Bennett, R.S.; Murphy, N.; Jahrling, P.B.; Patterson, J.L. Heparan Sulfate Is an Important Mediator of Ebola Virus Infection in Polarized Epithelial Cells. Virol. J. 2018, 15, 135. [CrossRef]

81. Buijsers, B.; Yanginlar, C.; Maciej-Hulme, M.L.; de Mast, Q.; van der Vlag, J. Beneficial Non-Anticoagulant Mechanisms Underlying Heparin Treatment of COVID-19 Patients. EBioMedicine 2020, 59, 102969. [CrossRef]

82. Liu, L.; Chopra, P.; Li, X.; Bouwman, K.M.; Tompkins, S.M.; Wolfert, M.A.; de Vries, R.P.; Boons, G.-J. Heparan Sulfate Proteoglycans as Attachment Factor for SARS-CoV-2. ACS Cent. Sci. 2021, 7, 1009-1018. [CrossRef]

83. Gozzo, L.; Viale, P.; Longo, L.; Vitale, D.C.; Drago, F. The Potential Role of Heparin in Patients With COVID-19: Beyond the Anticoagulant Effect. A Review. Front. Pharmacol. 2020, 11, 1307. [CrossRef]

84. Lertjuthaporn, S.; Cicala, C.; Van Ryk, D.; Liu, M.; Yolitz, J.; Wei, D.; Nawaz, F.; Doyle, A.; Horowitch, B.; Park, C.; et al. Select Gp120 V2 Domain Specific Antibodies Derived from HIV and SIV Infection and Vaccination Inhibit Gp120 Binding to A4 $\beta 7$. PLoS Pathog. 2018, 14, e1007278. [CrossRef] [PubMed]

85. Tan, C.W.; Sam, I.-C.; Chong, W.L.; Lee, V.S.; Chan, Y.F. Polysulfonate Suramin Inhibits Zika Virus Infection. Antiviral Res. 2017, 143, 186-194. [CrossRef] [PubMed]

86. Hyatt, J.G.; Prévost, S.; Devos, J.M.; Mycroft-West, C.J.; Skidmore, M.A.; Winter, A. Molecular Changes in Dengue Envelope Protein Domain III upon Interaction with Glycosaminoglycans. Pathogens 2020, 9, 935. [CrossRef]

87. Watterson, D.; Kobe, B.; Young, P.R. Residues in Domain III of the Dengue Virus Envelope Glycoprotein Involved in Cell-Surface Glycosaminoglycan Binding. J. Gen. Virol. 2012, 93, 72-82. [CrossRef]

88. Park, J.; Kang, T.-B.; Lim, J.-H.; Won, H.-S. Molecular Targeting of VEGF with a Suramin Fragment-DOCA Conjugate by Mimicking the Action of Low Molecular Weight Heparins. Biomolecules 2020, 11, 46. [CrossRef] [PubMed]

89. Basavannacharya, C.; Vasudevan, S.G. Suramin Inhibits Helicase Activity of NS3 Protein of Dengue Virus in a Fluorescence-Based High Throughput Assay Format. Biochem. Biophys. Res. Commun. 2014, 453, 539-544. [CrossRef]

90. Lee, E.; Lobigs, M. Mechanism of Virulence Attenuation of Glycosaminoglycan-Binding Variants of Japanese Encephalitis Virus and Murray Valley Encephalitis Virus. J. Virol. 2002, 76, 4901-4911. [CrossRef] [PubMed]

91. Chiou, S.-S.; Liu, H.; Chuang, C.-K.; Lin, C.-C.; Chen, W.-J. Fitness of Japanese Encephalitis Virus to Neuro-2a Cells Is Determined by Interactions of the Viral Envelope Protein with Highly Sulfated Glycosaminoglycans on the Cell Surface. J. Med. Virol. 2005, 76, 583-592. [CrossRef]

92. Kim, S.Y.; Koetzner, C.A.; Payne, A.F.; Nierode, G.J.; Yu, Y.; Wang, R.; Barr, E.; Dordick, J.S.; Kramer, L.D.; Zhang, F.; et al. Glycosaminoglycan Compositional Analysis of Relevant Tissues in Zika Virus Pathogenesis and in Vitro Evaluation of Heparin as an Antiviral against Zika Virus Infection. Biochemistry 2019, 58, 1155-1166. [CrossRef] [PubMed]

93. Leonova, G.N.; Belikov, S.I. Effect of Glycosaminoglycans on Pathogenic Properties Far-Eastern Tick-Borne Encephalitis Virus. Bull. Exp. Biol. Med. 2019, 167, 482-485. [CrossRef]

94. Rincón, V.; Corredor, A.; Martínez-Gutíerrez, M.; Castellanos, J.E. Fluorometric Cell-ELISA for Quantifying Rabies Infection and Heparin Inhibition. J. Virol. Methods 2005, 127, 33-39. [CrossRef] 
95. Jinno, A.; Park, P.W. Role of Glycosaminoglycans in Infectious Disease. In Glycosaminoglycans; Balagurunathan, K., Nakato, H., Desai, U.R., Eds.; Methods in Molecular Biology; Springer: New York, NY, USA, 2015; Volume 1229, pp. 567-585; ISBN 978-1-4939-1713-6.

96. Park, P.W. Glycosaminoglycans and Infection. Front. Biosci. 2016, 21, 1260-1277. [CrossRef]

97. Simon, E.J.; Linstedt, A.D. Site-Specific Glycosylation of Ebola Virus Glycoprotein by Human Polypeptide GalNAc-Transferase 1 Induces Cell Adhesion Defects. J. Biol. Chem. 2018, 293, 19866-19873. [CrossRef] [PubMed]

98. New Dengue Hemorrhagic Fever Findings from School of Medicine Discussed (Suramin Inhibits Helicase Activity of NS3 Protein of Dengue Virus in a Fluorescence-Based High Throughput Assay Format). Malar. Wkly. Atlanta GA 2015, 4.

99. Mire, C.E.; Chan, Y.-P.; Borisevich, V.; Cross, R.W.; Yan, L.; Agans, K.N.; Dang, H.V.; Veesler, D.; Fenton, K.A.; Geisbert, T.W.; et al. A Cross-Reactive Humanized Monoclonal Antibody Targeting Fusion Glycoprotein Function Protects Ferrets Against Lethal Nipah Virus and Hendra Virus Infection. J. Infect. Dis. 2020, 221, S471-S479. [CrossRef]

100. Bradel-Tretheway, B.G.; Zamora, J.L.R.; Stone, J.A.; Liu, Q.; Li, J.; Aguilar, H.C. Nipah and Hendra Virus Glycoproteins Induce Comparable Homologous but Distinct Heterologous Fusion Phenotypes. J. Virol. 2019, 93, e00577-19. [CrossRef] [PubMed]

101. Kalbhor, M.S.; Bhowmick, S.; Alanazi, A.M.; Patil, P.C.; Islam, M.A. Multi-Step Molecular Docking and Dynamics SimulationBased Screening of Large Antiviral Specific Chemical Libraries for Identification of Nipah Virus Glycoprotein Inhibitors. Biophys. Chem. 2021, 270, 106537. [CrossRef]

102. Dong, J.; Cross, R.W.; Doyle, M.P.; Kose, N.; Mousa, J.J.; Annand, E.J.; Borisevich, V.; Agans, K.N.; Sutton, R.; Nargi, R.; et al. Potent Henipavirus Neutralization by Antibodies Recognizing Diverse Sites on Hendra and Nipah Virus Receptor Binding Protein. Cell 2020, 183, 1536-1550.e17. [CrossRef]

103. Sun, B.; Jia, L.; Liang, B.; Chen, Q.; Liu, D. Phylogeography, Transmission, and Viral Proteins of Nipah Virus. Virol. Sin. 2018, 33, 385-393. [CrossRef]

104. Khusro, A. Hendra Virus Infection in Horses: A Review on Emerging Mystery Paramyxovirus. J. Equine Vet. Sci. 2020, 91, 103149. [CrossRef]

105. Das, S.K. The Pathophysiology, Diagnosis and Treatment of Corona Virus Disease 2019 (COVID-19). Indian J. Clin. Biochem. 2020, 35, 385-396. [CrossRef] [PubMed]

106. Sánchez, E.; Hernandez-Vargas, E.A. (Eds.) Chapter 5-Modeling Ebola Virus Infection. In Modeling and Control of Infectious Diseases in the Host; Academic Press: London, UK, 2019; pp. 85-103. ISBN 978-0-12-813052-0.

107. Salgado-Benvindo, C.; Thaler, M.; Tas, A.; Ogando, N.S.; Bredenbeek, P.J.; Ninaber, D.K.; Wang, Y.; Hiemstra, P.S.; Snijder, E.J. Suramin Inhibits SARS-CoV-2 Infection in Cell Culture by Interfering with Early Steps of the Replication Cycle. Antimicrob. Agents Chemother. 2020, 64, 11. [CrossRef]

108. Bauer, S.; Jin, W.; Zhang, F.; Linhardt, R.J. The Application of Seaweed Polysaccharides and Their Derived Products with Potential for the Treatment of Alzheimer's Disease. Mar. Drugs 2021, 19, 89. [CrossRef] [PubMed]

109. Zoepfl, M.; Dwivedi, R.; Taylor, M.C.; Pomin, V.H.; McVoy, M.A. Antiviral Activities of Four Marine Sulfated Glycans against Adenovirus and Human Cytomegalovirus. Antiviral Res. 2021, 190, 105077. [CrossRef]

110. Luo, Z.; Tian, D.; Zhou, M.; Xiao, W.; Zhang, Y.; Li, M.; Sui, B.; Wang, W.; Guan, H.; Chen, H.; et al. $\lambda$-Carrageenan P32 Is a Potent Inhibitor of Rabies Virus Infection. PLoS ONE 2015, 10, e0140586. [CrossRef] [PubMed]

111. Rentsch, C.T.; Beckman, J.A.; Tomlinson, L.; Gellad, W.F.; Alcorn, C.; Kidwai-Khan, F.; Skanderson, M.; Brittain, E.; King, J.T.; Ho, Y.-L.; et al. Early Initiation of Prophylactic Anticoagulation for Prevention of Coronavirus Disease 2019 Mortality in Patients Admitted to Hospital in the United States: Cohort Study. BMJ 2021, 372, n311. [CrossRef]

112. Pawlowski, C.; Venkatakrishnan, A.; Kirkup, C.; Berner, G.; Puranik, A.; O’Horo, J.C.; Badley, A.D.; Soundararajan, V. Enoxaparin Is Associated with Lower Rates of Mortality than Unfractionated Heparin in Hospitalized COVID-19 Patients. EClinicalMedicine 2021, 33, 100774. [CrossRef]

113. Hernando, P.J.; Dedola, S.; Marín, M.J.; Field, R.A. Recent Developments in the Use of Glyconanoparticles and Related Quantum Dots for the Detection of Lectins, Viruses, Bacteria and Cancer Cells. Front. Chem. 2021, 9, 668509. [CrossRef] 